\title{
PAVEL SKRINJAR O DANILU DOLCIJU
}

$\mathrm{P}$ Krasa, poznamo ga kot pobudnika za postavitev Kosovelove sobe $v$ Sežani in sedaj kot skrbnika Kosovelove sobe, ki zna povedati veliko zgodb o Kosovelovih. Poznamo ga tudi kot ravnatelja ljudske univerze, ki se je naveličal ravnateljevati, kot neutrudnega opisovalca dogodkov in ljudi iz preteklosti in sedanjosti kraškega življenja, kot oblikovalca Kosovelove poti, kot sogovornika v literarnih večerih ... Leta 2004 je ob obletnici rojstva Danila Dolcija odkril spominsko ploščo na mestu, kjer je stala Dolcijeva rojstna hiša. Zanimalo me je, kako je on doživel Dolcija kot človeka, saj se je z njim kar nekajkrat srečal.

\section{Danilo Dolci ni najbolj poznan v našem okolju, ne kot pesnik ne kot politik in tudi ne kot izobraževalec. Kako si se ti seznanil z njim?}

Spoznal sem ga leta 1979, ko smo pripravljali praznovanje 400-letnice lipiške kobilarne in smo sklenili, da pripravimo kulturno-literarno srečanje domačih avtorjev. Danila Dolcija sta poznali Vida Štolfa, ker je bila njegova mati, in Marija Karmela Kontelj, njena prijateljica. Poznala ga je tudi Jolka Milič, ki je v italijanskih časopisih brala poročila o njegovem političnem delovanju, o »škandalih «, ki jih je povzročal s svojim nenasilnim upiranjem. Prvič sem poskušal vzpostaviti stik z njim že okrog leta 1970, vendar mi na pismo ni odgovoril. Kasneje pa smo v nekem televizijskem intervjuju slišali, da bi rad prišel v svoj rojstni kraj, če bi ga kdo povabil. In smo ga povabili! In je prišel! Prvič 1979., 1980. je bil gost literarnega večera v Vilenici, pripravil je nekaj svojih pesmi prav za to priložnost. Sodelovali so še Ciril Zlobec, Aleksander Peršolja, Marko Kravos. Njegove pesmi je prevedla Jolka Milič.

\section{O Dolciju pišejo, da je bil podoben} Bezuhovu iz romana Vojna in mir. Bi ga res lahko primerjali s Tolstojevim likom?

Dolci je bil ogromne postave. Ko je prišel leta 1979 na tržaško letališče, ga nisem poznal, malo me je skrbelo, kako se bova seznanila. Pa ni bilo potrebno. Ko sem ga zagledal, sem vedel, to je on. Od vseh ostalih potnikov je bil za dve glavi višji, s svojim obilnim telesom je zajadral $\mathrm{k}$ meni in sva se pozdravila. Ampak kako! Objel me je in nevsiljivo pobožal po licu. Mogoče je to odsev italijanskega načina pozdravljanja, ko je telesna bližina del pozdravov, vendar se mi je zdelo, da ima Dolci posebno karizmo, ki jo je telesni izgled le dopolnjeval. Bil je velik, obilen možakar z očali in nasmehom, ki je razorožil vsakogar. Meni se je zdelo, da se poznava že zelo dolgo, čeprav sem ga prvič videl.

Veliko je spraševal in veliko je želel izvedeti. Pazljivo je poslušal. Zanimalo ga je samoupravljanje, ki je živelo v tedanji Jugoslaviji, zanimali so ga sodobni jugoslovanski pesniki ... Moral sem mu razlagati toliko časa, da je razumel. Pa ni bilo težko pripovedovati celo o tako zapletenih stvareh, kot je bila samoupravna interesna skupnost za kulturo, ker je spraševal in tudi sam pomagal pri razlagi. 
Včasih mi je ponudil več odgovorov in sem lahko samo prikimal.

Ko je prišel v Sežano, je bil navdušen. Najbolj so ga očarale kraške jame. Povedal mi tudi zanimivo dogodivščino. Ko sta šla z Viktorjem Saksidom iskat neko jamo na Brestoviškem, je nista mogla najti. Odšla sta $v$ vas in v prvi hiši povprašala, če vedo, kje je vhod v jamo, Gospodinja jima je nekaj časa razlagala, potem pa je poklicala svojo najstniško hčerko in jima rekla, da ju bo ona spremila do vhoda $v$ jamo. Vhod so hitro našli, jamo so si ogledali. Dolci je bil navdušen nad jamo, še bolj pa se je čudil nad zaupanjem ljudi - kako je mati poslala svojo hěerko z dvema moškima v gmajno! Takšno zaupanje!

Najbolj je bil očaran nad Vilenico. Še posebej mu je bila všeč velika dvorana, kjer so sedaj prireditve ob literarni nagradi Vilenica. Ogledoval si je prostor, plosknil z rokama in poslušal. Dejal je, da bi bil to odličen prostor za prireditve in koncerte. In še dodal, da ljudje razmišljamo o nebesih kot o nečem tam zgoraj, toda nebesa so povsod okrog nas. Lepota je povsod okrog nas in jame so nebesa pod zemljo.

\section{Dolci velja za italijanskega Gandija, boril se je za male ljudi. Se ti zdi, da bi ga lahko primerjali z Virgilom Ščekom, kraškim prosvetljevalcem, izobraževalcem?}

$\mathrm{V}$ nekaterih potezah prav gotovo. Dolcija so obkrožali preprosti ljudje, verjeli so, da se bo stanje spremenilo, če bodo le držali skupaj. Oba sta želela izobraževati ljudi, oba sta želela spodbuditi ljudi, da bi se zavzeli za svojo svobodo. Oba sta bila dobra govornika. Dolcija so imenovali Ghandi zaradi njegovega nenasilnega upiranja, zaradi nenasilnega pritiska na javnost in oblast. Propagiral je solidarnost, demonstriral je za boljše življenje. Zato so ga zaprli kot »hujskača«, oblast ni bila navdušena nad njegovim delom.
Bolj so bili navdušeni italijanski in tuji intelektualci, npr. Moravia, Silone, Levi ...

Omenjaš pomembne italijanske literate. Kako doživljaš Dolcijevo pesniško delo? Je v svoje verze prepletel tudi svoj politični program?

Težko rečem, verjetno da. Ne more pesnik mimo človeka, ki je doživel šestindvajset procesov, iz pesmi govori človek s svojimi doživetji in razmišljanji, občutenji. Njegove pesmi so težko prevedljive, metafore imajo socialni naboj, ki svöj pomen najde $v$ italijanskem jeziku v drugih besedah. Ena od njegovih pesniških zbirk ima naslov Bog klopov /Il Dio delle zecche/, kjer s klopi označi ljudi, ki se potiho in nesluteno prisesajo na druge ljudi, ti pa šele po dolgem času začutijo, kako jim sesajo kri. V kraški pokrajini se je izoblikovala metafora vode, ki dolbe kamen, primerja jo $\mathrm{z}$ naravo, ki oblikuje človeka. Kaplja vode je le kaplja, je nenasilna, toda sčasoma izdolbe kamen. Dolci je optimist, morda utopist. Tudi $v$ svojih pesmih je prepričan, da bo narava oblikovala človeka $v$ nekaj dobrega in lepega. Ne bi mogel reči, ali je bila poezija samo način izražanja socialnih problemov, ali je poezijo uporabljal, da bi pokazal na socialne probleme, ali pa so vse stiske, ki jih je doživljal, le spodbujale pesniško muzo.

\section{Kot razumem, si ga ti doživel kot nežnega človeka, ki zna poslušati ...}

Za Dolcija bi rekel, da je bil izjemno pronicljiv človek s smislom za rázlago in spraševanje, ob njem so se ljudje počutili varne. Politično je imel največ podpore $v$ skandinavskih državah, kjer so ljudje vajeni demokratično reševati probleme, $\mathrm{z}$ besedo, na miren način. Mogoče kot zanimivost: njegova druga žena je bila Švedinja. Njegov nenasilni protest je bil svetovno poznan, toda $v$ se- 
demdesetih letih so se radikalnejši somišljeniki naveličali čakati na rezultate. Odmaknili so se od njegovega gibanja in ustanovili nove politične skupine. Tihi odpor proti mafiji in izkoriščanju ni bil dovolj.

\section{Kosovelovi sobi imate precej njegovih} knjig. Vam jih je on poslal?

Všeč mu je bila Kosovelova soba in zamisel, da bomo tukaj zbirali dela pesnikov in pisateljev, ki so povezani s Sežano. Do svoje smrti je pošiljal v Sežano na Ljudsko univerzo svoja objavljena dela, tako da imamo v Kosovelovi sobi skoraj vsa njegova dela $\mathrm{v}$ italijanščini in tudi $v$ tujih jezikih, npr. češčini, švedščini, nemščini ...

Dolci je tudi predaval v Kosovelovi sobi o življenju ljudi na Siciliji. Pripovedoval je o revščini. Prostoročno je narisal krog, da je potem z deleži statistično prikazal življenje na Siciliji. Krog je bil takšen, kot bi ga narisal s šestilom.

Svoja dela nam je poslal kmalu po obisku v osemdesetih letih, povabil nas je tudi na Sicilijo, da bi tam spoznali njegovo delo. Bil je občudovalec kraške pokrajine, zanimale so ga kraške rastline, ruj in drugo cvetje ... in nekaj kraškega je bilo tudi v njegovem temperamentu: ni imel dlake na jeziku.

\footnotetext{
Pogovarjala se je dr. Nives Ličen
} 